\title{
Care: the missing link in economic analysis?
}

\author{
Corina Rodríguez Enriquez
}

ABSTRACT

This article sets out to synthesize the contribution of feminist economics to economic analysis by expounding, explaining and highlighting the functional role of domestic and care work. It notes the inadequacy of the treatment given to this subject over the years by the different schools of economics, before going on to set out just why this dimension is essential to an understanding of system functioning. It also deals with the conceptual, methodological and economic policy implications of incorporating this dimension of analysis, and with its relevance to the effort to carry forward an agenda that addresses the economic dimensions of gender inequity.

KEYWORDS

JEL CLASSIFICATION

AUTHOR
Economics, feminism, economic analysis, incorporation of the gender perspective, women, family welfare, unpaid work

$\mathrm{J} 16, \mathrm{~B} 54, \mathrm{~J} 13$

Corina Rodríguez E., Researcher with the National Council of Scientific and Technical Research (conicET) - Argentina, Consultant with the Gender Affairs Division of EcLAc. crodriguezenriquez@ciepp.org.ar 


\section{I}

\section{Introduction}

For decades, economics has sought to explain how (in economic terms) the world works. In order that everyone might understand it, the world has been represented in stylized and simplified forms. Capitalist societies are thus understood as a system of relationships between households, firms and the State. These institutions interact to produce and distribute the goods and services people require to satisfy their needs and desires, making the best possible (or, as we economists put it, optimal) use of the resources — scarce by definition - that the planet provides.

In its zeal for constructing models, the dominant approach in economics (based mainly on elaborations of neoclassical economic theory) has tended to play down the importance of political, social and cultural dimensions in this analysis, as these are difficult to formalize with mathematical instruments, the preferred tool for conventional analysis. This risks opening up a more or less substantial gap between the representation of reality and reality itself. Economics could thus progressively lose its explanatory power and thence its relevance as a social science that is necessary for the generation of knowledge of use not only in understanding the world, but also (and perhaps most importantly) in changing it.

This situation has been identified and criticized in a variety of heterodox approaches within the discipline of economics and an effort made to produce knowledge from alternative perspectives. An example of this is feminist economics, ${ }^{1}$ a school of thought that emphasizes the need to factor in gender relations, as an important variable in the functioning of the economy, and the different positions of men and women as economic agents and subjects of economic policies. ${ }^{2}$

\footnotetext{
${ }^{1}$ For a seminal work from the perspective of feminist economics, see Ferber and Nelson (1993) and its updated version, Ferber and Nelson (2003). For a survey of work done in this field from a Latin American perspective, see Esquivel (2011a). Also consult www.iaffe. org and www.gemlac.org.

2 The concept of gender as a social category of analysis is one of the most significant theoretical contributions of contemporary feminism. It arose to explain the inequalities between men and women and the way the idea of the female and the male had developed on the basis of a mutual cultural and historical relationship. Gender is a crossdisciplinary category that refers to the psychological and sociocultural characteristics and functions attributed to each of the sexes at each point in history and in each society. Historically constructed gender relations are systems of power, with hegemonic discourses. The
}

One of the central arguments of feminist economics is that it is necessary and important for economic analysis to bring out the fundamental role played by the work that must be done to produce and reproduce people, broadly known as care work.

Why is this important? Firstly, because without care work there would be no labour force, and consequently no way of generating economic value and reproducing the economic and social system. Secondly, because, by failing to recognize this dimension, economic analysis has become lopsided and not only provides an incomplete diagnosis of system functioning, but is subject to a high likelihood of error when the real repercussions of economic policies are evaluated. Thirdly, because the way care is organized in society, i.e., the way care responsibilities are distributed between State, market and households, on the one hand, and between men and women, on the other, accounts for a substantial proportion of the inequalities that currently exist. At least two things need to be highlighted here. First, the presumption that the sexual division of care work is at the root of gender inequalities, which are manifested in this and other areas (particularly the labour market). Second, that the options for organizing care activities differ by social class, and this results in different opportunities of access to and enjoyment of welfare.

Consequently, appreciating the systemic functional role of care work supplies an essential missing link in economic analysis. Again, understanding and casting light on the social organization of care can lead to the creation of tools for the design of actions to reduce or remove inequalities, and thus to progress towards a fairer society.

The purpose of this study is to present the essential contributions made by feminist economics

\footnotetext{
"problematization" of gender relationships was able to dispel the idea that they were natural. The term "gender perspective", when used to refer to the theoretical frameworks adopted to research or develop policies or programmes, means: (i) recognizing the power relationships that arise between the genders, these being generally favourable to men as a social group and discriminatory for women; (ii) acknowledging that these relationships have been socially and historically constituted and are constitutive of persons; and (iii) appreciating that they pervade the whole fabric of society and interact with other social relationships, such as those of class, ethnic origin, age, sexual preference and religion (Gamba, 2007).
} 
as regards the inclusion of care in economic analysis. To this end, section II provides an overview of the way economics deals with the issue of care. Section III presents a proposal for including the care dimension in economic analysis. Section IV reviews the theoretical, methodological and public policy implications that arise when the issue of care and its organization in society is addressed.

\section{II}

\section{How economics deals with care ${ }^{3}$}

Economic theorizing about the concept of work (for the market) and its relationship with care work, essentially meaning domestic work, began with the classical economists. They identified the importance of workforce reproduction, but concentrated on the matter of the "wage goods" consumed by households, without exploring the role of domestic work in this process. This was because their interest centred on the relationship between the value of labour (its natural price) and the price of labour (wages) as set in the market. David Ricardo considered that the "natural price" of labour was given by the value of the subsistence goods consumed by workers, without which they could not participate in production processes and thus create wealth. Its level was based on the historical costs of reproduction for workers and their families, which set a minimum threshold below which wages could not fall without inducing a drop in birth rates. In developing this argument, David Ricardo ignored the contribution of domestic work to workers' and their families' reproduction process, concentrating instead on the potential conflict between the rate of return and the cost of reproduction of the workforce, as determined by the value of wage goods.

In the context of this discussion, the classical economists accepted as natural the hierarchical model of marriage and the family. ${ }^{4}$ Thus, Adam Smith considered that the self-interest which drove people's actions in the marketplace was diluted within households, where altruism prevailed instead. He considered that society needed a sphere of social relations that was guided by moral criteria and not by criteria of efficiency. It was the household, and particularly the role of women within it, that provided the necessary counterweight to

\footnotetext{
${ }^{3}$ Here I mainly follow the reading of Gardiner (1997) found in Rodríguez Enríquez (2001).

${ }^{4}$ The exceptions are John Stuart Mill and Harriet Taylor, who recognized the importance of women participating in the employment market as an essential element in the democratic distribution of decision-making and responsibilities within the home.
}

the individualism and materialism of the market. From this perspective, unpaid care work would be seen as an expression of this altruism and these moral sentiments.

When Marx developed his theory of labour value, on the other hand, he recognized as labour both that which was productive in capitalist terms (work producing commodities, i.e., goods and services, with an exchange value) and that which was socially productive (work producing goods and services with a social value). ${ }^{5}$ However, the emphasis of Marx's analysis was on capitalist production relationships, and he therefore dealt only marginally with domestic work. In a sense, Marx took up a position similar to Ricardo's, circumventing the problem of domestic work by assuming that capitalists provided everything necessary to the reproduction of the workforce and that only consumption of commodities took place within the home (and not production or processing of these by means of domestic work and unpaid care).

Engels, on the other hand, did go quite thoroughly into the role of the family in the capitalist system. Thus, he further developed the idea, put forward in his early writings with Marx, that the main objective of the institution of the family was to ensure the transmission of private wealth down the generations. ${ }^{6}$ In his observation, Engels argued that, within the context of the patriarchal family, the organization of households and the care given to their members (mostly by women) became a private service that did not form part of social production. Engels even went so far as to identify the strain created in this context by the growing need of capitalism to incorporate women into the workforce. What was never

\footnotetext{
${ }^{5}$ Gardiner (1997) argues that the development of Marxist theory in relation to the issue of domestic work can be traced back mainly to the first three volumes of Marx's Capital and to his Theories of Surplus-Value and to Engels' contributions in The Condition of the Working Class in England and The Origin of the Family, Private Property and the State.

${ }^{6}$ In this context, patriarchal control of women by men implies husbands controlling their wives' sexuality and fertility as a way of ensuring indisputable heirs (Gardiner, 1997).
} 
questioned from this original Marxist standpoint was the sexual division of labour, nor was consideration given to the possibility of redistributing the burden of care between men and women. Indeed, the view was taken that women could only free themselves from this burden and achieve equality with men once domestic and care work had become socialized.

With the subsequent development of the marginalist school, this aspect disappeared completely from view. ${ }^{7}$ By considering labour exclusively as a factor of production that individuals traded in the marketplace, it divorced the price of this (the wage) from any social or historical process. Because economic value was tied to the ability and desire to make this trade, any unpaid work (or work for which there was no market) ceased to be treated as an object of analysis. Also omitted was any consideration of the factors leading individuals to offer or withhold their labour in the labour market. ${ }^{8}$

While not considering it an object of economic study, however, Marshall recognized the importance of the domestic work done by women in the home. Thus, he argued for the importance of reinforcing the necessary altruism of women, to which end he advocated a family wage for all male workers and considered that the minimum wage required for the reproduction of the workforce should also be sufficient to support wives. His stance against the incorporation of women into the labour market is consistent with this. Pigou took much the same line in his "welfare economics", where he argued that poor women, and mothers in particular, ought to receive financial assistance from the State so that they could perform their domestic work properly without having to look for a job.

Subsequent developments in this school of thought, now consolidated as neoclassical theory and the dominant outlook in economics, sought to explain the seeming paradox of a rising labour force participation rate among married women at a time when wages (and thus household incomes) were increasing. Progress was also made in adapting market concepts to the analysis of activities within the home. The so-called new home economics synthesized this theoretical approach. ${ }^{9}$

\footnotetext{
${ }^{7}$ Principles of Economics, published in 1890 by Alfred Marshall, is the text that is most representative of the early development of this school of thought.

${ }^{8}$ From this perspective, and on the assumption that all individuals are rational economic agents, the decision to offer or withhold labour in the marketplace is in fact seen as being driven by the quest for an optimal personal situation, and thus as the best possible decision (and the only one in equilibrium).

${ }^{9}$ Mincer (1962) and Becker (1965) wrote the founding texts of this school.
}

From this perspective, households are deemed to be harmonious, rational and ahistorical units. In them, people make rational decisions about the distribution of their time between activities for the market (paid production work), activities for the home (unpaid domestic and care work) ${ }^{10}$ and leisure. ${ }^{11}$ Becker, who went closely into this aspect, considered that households acted as a unit following the rational choice model ${ }^{12}$ and maximizing the shared utility of their members, who were subject to time and income constraints. The traditional gender division of labour within the home is considered to be a rational economic response by the household to the value the market places on the time of each of its members, something that in turn is taken to reflect individuals' productivity in the marketplace. ${ }^{13}$

\section{The meeting of economics and feminism in the study of care ${ }^{14}$}

In the realm of feminist theory, the "domestic labour debate" turned back to Marxist theory. The main point of discussion was the relationship between domestic work and capital accumulation. Two basic positions were taken. One was that domestic work subsidized capitalist production through its role in the reproduction of the labour force, thus directly increasing capitalist profits. The other refuted the idea of a subsidy, instead treating domestic work as essential to the reproduction of the labour force in societies of this type.

The first position redefined the value of the labour force as the total working time necessary for its reproduction, i.e., the time spent on care work in the home, plus the abstract time incorporated into the commodities

\footnotetext{
10 This perspective revives the classical idea of self-interested and competitive behaviour in the marketplace coexisting with altruistic behaviour in the home (which is thus the preferred setting for certain types of work requiring altruism, such as care).

${ }^{11}$ Implicit in this theory is that men choose between work (in the marketplace) and leisure, while women choose between work in the home (and leisure) and work in the marketplace.

${ }^{12}$ In this connection, see in particular his text The Economic Approach to Human Behaviour.

13 Thus, gender differences in employment patterns are explained as resulting from the cumulative effects of the individual and household decisions of men and women, who respond rationally to the signals given out by the market regarding their comparative advantages in the different spheres of production. Empirically, this means, for example, that if young men and women start by being equally productive in both spheres of production, gender discrimination in the labour market (which reduces women's wages below their market productivity) will mean that women take on a larger share of domestic work and men a larger share of remunerated work in the market (Gardiner, 1997).

${ }^{14}$ This draws on some ideas set forth in Marco Navarro and Rodríguez Enríquez (2010).
} 
consumed. Thus, surplus value is appropriated by the capitalists, who pay male workers a wage that is less than the value of their labour.

Accordingly, the contribution made by domestic work to the production of surplus value is to keep the value of the labour force below its cost of reproduction. The mechanism for this is the retention within the home of those aspects of reproduction and maintenance of the labour force that are not profitable either for capitalist production or for the State, in the event that the latter were to take on responsibilities in this area. The future configuration of domestic work would thus appear to depend on the relationship between labour force reproduction costs, the capital accumulation process and the demand for remunerated female labour.

The perspective that treats domestic work as an indispensable element in the survival of the capitalist mode of production views it as production in itself, not of commodities this time, but of use value. Its ultimate purpose is to provide labour that can be sold. From this perspective, the main reason domestic labour survives is that capitalism requires workers who are free individuals offering their labour in the market.

The "domestic labour debate" did not explore the problem of gender relations or ask whether men might be benefiting from domestic work as well as (or rather than) capitalists. Likewise, little attention was paid to the fact that it was the combination of domestic work and paid work, rather than domestic work alone, that characterized the experience of women under capitalism. Some of these things were discussed in the "patriarchy debate".

Three perspectives can be distinguished within this line of thinking. ${ }^{15}$ The first uses a strict definition of the patriarchal family, identifying it with households containing a head, an economically dependent female spouse, and children. Men thus have a common interest in having a woman available to serve them within the home. As women gain access to the labour market and secure other measures of social equity, men's authority within the family declines and gender segregation in jobs becomes the main way of perpetuating the economic dependence of women in the patriarchal family. In today's industrial societies, accordingly, a new agreement has arisen between patriarchy and capitalism whereby married women are wage workers and domestic workers, an agreement based on wage differentials and occupational

\footnotetext{
15 There is a fourth perspective, which is the one developed by black women, mainly in the United Kingdom and the United States.
}

segregation, perpetuating the economic dependency of women (Hartmann, 1981).

A second perspective in this debate argues that the term patriarchy is more appropriately reserved for situations where society is organized upon identifiably patriarchal models and where physical violence and ideology combine with economic mechanisms to produce a systematic subordination of women. Consequently, patriarchy is based on the social relationships of human reproduction, i.e., on control over women (and children) by men, and especially on control over their sexuality and fertility. ${ }^{16}$

The third approach is one that places the debate within a global and environmental perspective. Mies (1986), the main exponent of this approach, contends that capitalist patriarchy is a global system that subjects women. In this system, domestic work (the production of life and values in use to meet human needs) is essential for capital accumulation because it is vital to the existence of wage-paying work. The role of women as spouses is necessary both to reproduce the labour force and to reduce competition with male workers in the labour market, in addition to the fact that they become consumers.

More recently, feminist economics has made large contributions to the study of unpaid work, highlighting its gender aspects, its invisibility and its key contribution to social reproduction and the functioning of the economy. Studying the realm of what was labelled the "care economy", it has demonstrated the invalidity of many of the assumptions of conventional microeconomic models. Thus, it has argued that "instead of challenging the traditional division of labour whereby men 'specialize' in remunerated work and women in domestic work or other unpaid activities, these models take a number of (static) gender characteristics for granted -i.e., women are better cooks than men and better at childcare, while men do better in the labour market - with the aim of explaining and justifying the traditional division of labour and the inequities associated with it inside and outside the home" (Benería, 2003b, p. 41).

As noted by Esquivel (2011a, p. 2), the concept of the care economy "has the advantage of tying together the different signifiers of 'economy' - the realm of the market, money and production, where income is generated and the living conditions of the population are determined - with 'care', the private, everyday realm of feeling and affection [...] the care economy

16 The main exponents of this approach are Mackintosh (1977) and Folbre (1994). They note that it is not only men who benefit from domestic work but also future generations and society as a whole. 
shifts the focus from the old emphasis on the costs of those giving care (women) to the new emphasis on the contributions made to the welfare of those receiving it (Benería, 2003b, p. 169). Since recipients of care are essentially taken to be groups of dependents (small children, older adults, the sick and disabled), the care economy overlaps with debates about social protection, which is also organized around the idea of the 'risks' to which certain population groups are subject." Thus, the care economy "emphasizes the relationship between the care given to children and older adults in the domestic realm and the characteristics and availability of both State and private-sector care services (Folbre, 2006; Himmelweit, 2007; Razavi, 2007).”

This extension of the sphere of analysis with regard to care reveals how the "feminization" of care reaches beyond the home, with the naturalization of female overrepresentation in certain remunerated care activities (in the health-care sector, education and domestic service). ${ }^{17}$ Care thus takes on the characteristics of a public policy problem that goes beyond the strict realm of private life and its naturalization as a female concern.

In sum, the care economy, as conceptually and analytically conceived by feminist economics, seeks not only to gauge, measure and give prominence to care and incorporate the sectors providing it (including households) into economic analysis, but to articulate a position that questions the functioning of the economic system and the way this is interpreted. As pointed out by Nelson (1993 and 1996), it advocates a movement in the central focus of economic analysis away from trade and choice to provisioning, i.e., to the goods and processes necessary for human survival.

${ }^{17}$ Empirical analyses have shown how those working in these feminized sectors are penalized with lower wages and poorer working conditions.

\section{III}

\section{Incorporating care into economic analysis: the expanded circular flow of income}

One way of understanding how gender relations permeate the workings of the economic system is to employ the conceptualization of conventional economics and extend it to incorporate the missing dimensions. This is what is done by Picchio (2001 and 2005), who is concerned to define the process of social reproduction of the population and situate it within the dynamic of the economic system.

This concern ties in with one of the basic elements in the feminist argument, which is the need to give visibility to the gender dimensions that are manifested in the relationship between production and reproduction, whose structuring perpetuates the economic subordination of women by limiting their autonomy.

Picchio (2005) argues that the tension between producing commodities and reproducing people derives from the nature of the labour market, which represents a particular historical way of trading work for the means of subsistence, a central aspect of capitalist organization. ${ }^{18}$

${ }^{18}$ Following the social theory tradition of classical economics, Picchio (1992) uses the term subsistence to mean a state of sustainable living
The key point here is that for the necessary endowment of the labour factor to be available, another endowment of labour is needed to carry out the social reproduction of people, and this is not taken into account in conventional economic analysis.

As already mentioned, the main contention of feminist economics in this regard is that the "sexual division of labour" - which encompasses the distribution of productive and reproductive work ${ }^{19}$ between households, the market and the State, on the one hand, and between men and women, on the other- entails the economic subordination of women, as manifested in lower participation in paid work (and greater participation in unpaid work), a worse position in the labour market (in terms of pay and working conditions), less access

standards. In the case of paid work, the indicator used to identify this condition is a set of commodities conventionally considered necessary for the reproduction of workers and of the working population as a "species".

${ }^{19}$ The idea of reproductive work employed here is equivalent to the domestic and care work mentioned earlier. 
to economic resources and, in consequence of all this, a lower degree of economic autonomy. ${ }^{20}$

To grasp the social character of reproductive work, it is important to appreciate the historical link between the production and reproduction processes. A separation has arisen between the two in the capitalist system, and this has led to the creation of separate spheres, institutions, social organizations, norms and even cultures that distinguish paid work from unpaid reproductive work. This separation has been instrumental in concealing the links between the different types of work and the different processes (Picchio, 1992 and 1999).

To succeed in altering the analytical approach and centring it on the social reproduction process, Picchio (2005) considers it necessary to "situate the process of social reproduction of the working population in relation to the process of resource production, a central issue in the dynamic analysis of the classical economists" (Picchio, 2005, p. 23).

For this, Picchio (2001) suggests expanding the "traditional schema of the circular flow of income" by incorporating an economic space which might be termed the space of reproduction, ${ }^{21}$ in which three economic functions undertaken within the private realm of households are distinguished. These functions, whose position in the expanded circular flow of income can be seen in figure 1, are as follows:

(i) expansion or extension of monetary income (real wages) in the form of expanded living standards (actual consumption), i.e., cooked food, clean clothes, etc.; in other words, commodities purchased with the monetary wage are included, as is the transformation of these goods and services into actual consumption through the mediation of unpaid domestic and care work;

(ii) an extension of expanded living standards (consumption) in the form of an effective welfare condition; ${ }^{22}$ this consists in the enjoyment of

${ }^{20}$ Evidence from time-use surveys reveals that: “(i) the amount of unpaid social reproduction work (domestic and care work and others) is greater than the total amount of paid work done by men and women, and (ii) the gender distribution of work (paid and unpaid) presents very marked disparities in all countries" (Picchio, 2005, p. 25).

${ }^{21}$ Picchio (2001) terms it the space of human development, but this could be confused with the concept associated with the Human Development Index calculated each year by the United Nations Development Programme (UNDP), or with the concept of human capital, which conversely refers to an instrumental use of people as production inputs requiring ongoing training and proper application to increase their productivity.

22 Picchio (2005), following Sen (1985) and Nussbaum (2000), understands welfare as a set of human capabilities and effective functionings in the social realm. specific and conventionally appropriate levels of education, health care and social life, made possible by the mediation of unpaid care work (consisting, for example, in ensuring children attend school, monitoring their health, ensuring they have recreation and stimulation, etc.);

(iii) reduction or selection of population segments and individual capabilities to be used as a factor in the commodities and services production process in the market economy. In this case, unpaid work done in the domestic realm plays a supporting role in the selection (carried out in the labour market) of the people and individual capabilities actually employed in production processes, materially and psychologically facilitating adaptation to these and absorbing the strains they generate.

The expanded circular flow of income (see figure 1) brings the mass of unpaid care work to light and relates it to economic agents and the system of production, and to the effective welfare of individuals. ${ }^{23}$

How should figure 1 be interpreted? The upper section reproduces the traditional circular flow of income, which discriminates the monetary and real flow of production and distribution in the commercial sphere. As can be seen, this representation does not encompass what happens within households, which includes both the transformation of goods and services into effective welfare that allows people to reproduce, and the administration of the workforce that determines what labour is available for the market.

This is what is added in the lower section of figure 1, where the market sphere is joined by the reproductive one. The first thing that can be noted there is the inclusion of unpaid work. This encompasses all activities carried out by households to ensure the reproduction of their members, including the specific work of care (of dependents, including children and the elderly and infirm, but also people capable of looking after themselves, such as spouses) and domestic work (home maintenance, cleaning, administration of the home, repair of installations, etc.).

Once households have acquired the goods and services they require to satisfy their needs and desires in the commercial marketplace, they need to turn them into effective consumption. Thus, adding unpaid work

\footnotetext{
${ }^{23}$ It should be pointed out that this framework of analysis excludes public policies, which operate both in regulating production and the wage fund and in expanding people's welfare. Links to the external sector are also excluded, given that the objective is to situate the reproduction process in relation to that of production and not to carry out a complex analysis of the workings of the economic system.
} 


\section{Circular flow of income}
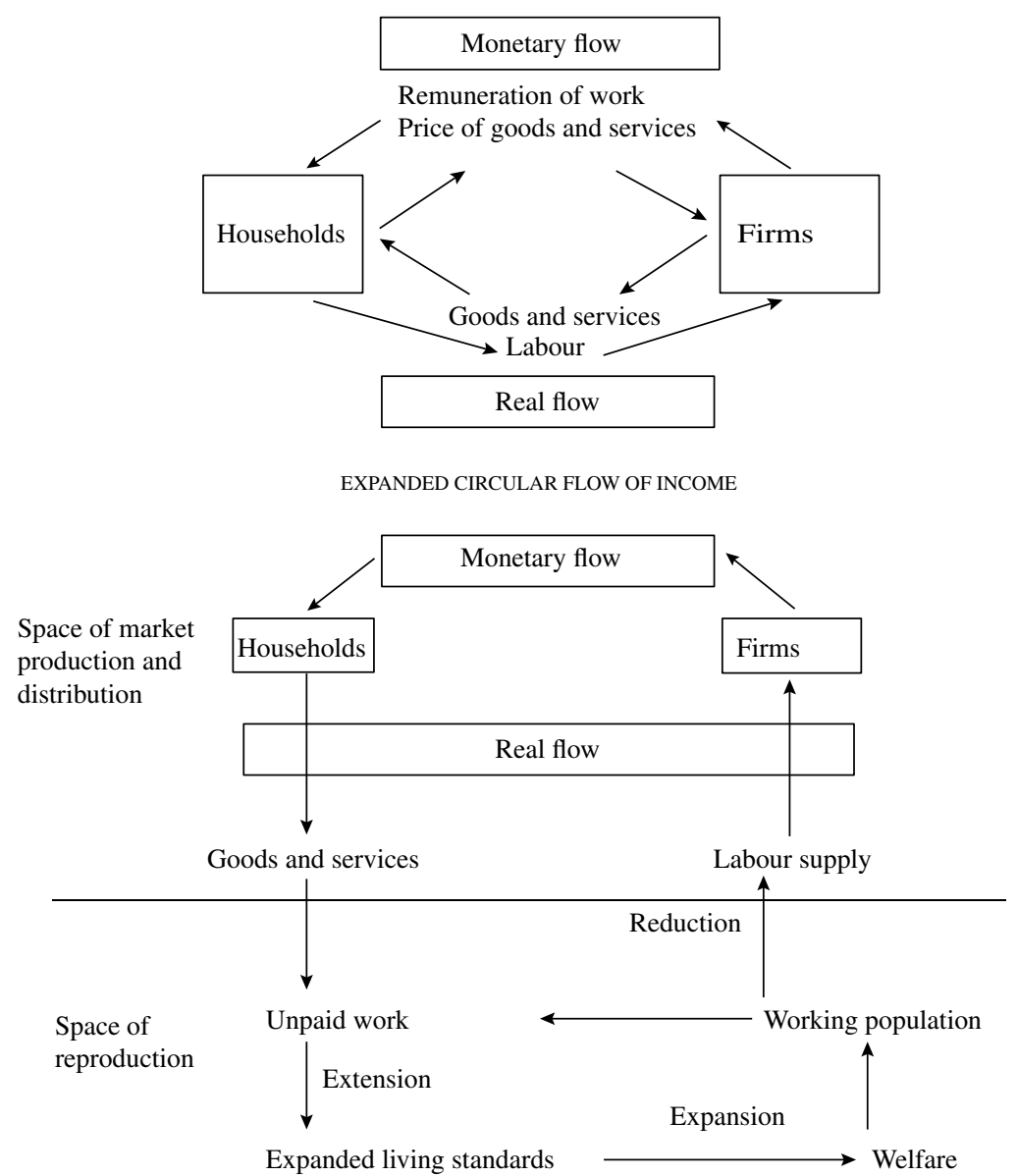

Source: prepared by the author on the basis of A. Picchio, "Un enfoque macroeconómico ampliado de las condiciones de vida", paper presented at the inaugural conference of the "Tiempos, trabajos y género" congress, Barcelona, University of Barcelona, 2001.

to goods and services results in this consumption being extended into expanded living standards.

It is also people's unpaid care work that turns these living standards into welfare, through activities related to health care, education, leisure, etc. It is precisely the recognition of needs, capabilities and aspirations that characterizes what in this context is defined as "the income expansion process, termed welfare" (Picchio, 2001, p. 15).

By contrast with the conceptualization of households adopted for the traditional circular flow, ${ }^{24}$ with the

\footnotetext{
24 This conceptualization derives from the same body of theory and matches that of the new home economics, touched upon in the previous section.
}

expanded flow households are not treated as harmonious institutions. On the contrary, the inclusion of unpaid work in the analysis gives greater complexity to households, whose members must now explicitly negotiate and decide how labour is to be divided up between them. ${ }^{25}$ This is the process whereby only a portion of the available workforce is made available in the marketplace. Thus, households make possible the reduction of the supply of labour required in the market through the relationship between their own requirements for unpaid labour and the conditions prevailing in the labour market. To put it

\footnotetext{
25 The idea of households as inharmonious units, riven by conflicting interests and asymmetrical power relationships, ties in more closely with the notion of cooperative conflicts developed by Sen (1990).
} 
another way, the supply of paid labour is regulated by the negotiations carried out within households to distribute unpaid labour to reproductive tasks.

In figure 1, this process is manifested in the fact that not all of the working population forms part of the labour supply. Or, more strictly, not all of the endowment of labour at people's disposal is actually made available in the market. This is because there are people who remain completely outside it, as they are employed full-time on care and domestic activities, or because they implement strategies combining part-time work for the market with their everyday employment on unpaid work. ${ }^{26}$

The process of distributing labour within households is part of the sexual division of labour, which is determined by both cultural norms and economic rationality. The existence of discrimination in the labour market is thus seconded by the traditional division of domestic and care responsibilities, accounting for the persistence of a sexual division of labour that places most of the responsibility for reproducing people upon women.

The pressure on unpaid labour is unremitting, as it is this that has to cover the gap between available income and social consumption norms and, most particularly, between the conditions of remunerated work and living conditions. The expansion of income through unpaid work is a real process that serves to reduce the discrepancy between the resources distributed and actual family consumption (Picchio, 2001).

At the same time, unpaid work is not infinitely elastic either. Its potential for arbitrage between the labour market and living conditions declines when new opportunities arise for some segments of the labour force (including women). The problem of the growing tensions between the conditions of the social reproduction process and the conditions of commodity production cannot be resolved by symbolically enhancing women's capabilities without also going into the internal contradictions of the system as regards the formation of social capital, the norms of social living and the appropriateness of the remuneration for labour.

When unpaid care work is integrated in this way into the analysis of capitalist production relationships, it can be appreciated that a transfer takes place from the domestic sphere to the accumulation of capital. Briefly, it might be said that the unpaid care work done in households (mostly by women) constitutes a subsidy to the rate of return and capital accumulation.

\footnotetext{
26 Obviously, and increasingly, there are also people who combine full-time working days for the market with their unpaid working days.
}

Picchio (1999) formalizes this relationship by including unpaid work in the macroeconomic aggregates from a classical standpoint. Thus, she establishes that commodity production incorporates not only paid production work, but also unpaid reproduction work (which is incorporated into the remunerated labour force). Consequently, some of the analytical implications of this approach can be conjectured. ${ }^{27}$

It is possible to define a simple relationship where product $P$ is a function of wage labour $(L w)$ and domestic and care labour $(L d)$.

$$
P=f(L w+L d)
$$

The product is distributed between labour (wage and domestic) and profit $(R)$, so that:

$$
P=L w W+R+L d O
$$

The share of $P$ corresponding to domestic labour is nil, as its wage is nil. It might be said that part of the product ends up in the hands of those carrying out the care work because of a rule of distribution of $W$ within households, but this is indeterminate (and would exceed the specific component of the family wage). In fact, the relationship between domestic labour and the other variables $(L w, P, W, R)$ would need to be specified.

Domestic labour influences the amount and quality of wage labour $(L w)$. Its effect on the quality of $L w$ is related to the values transmitted through education within households and to the health care carried out there. Domestic labour also influences the number of hours of wage labour available, as it releases this from care responsibilities.

The role of domestic labour in relation to $W$ is very important, as there is a degree of substitution between domestic labour and wage commodities, and living standards do not depend exclusively on commodities because non-commercial goods and services are important too.

Likewise, insofar as $W$ is inversely related to $R$, the share of $W$ corresponding to intra-household resource transfers will also depend on the degree of exploitation of capital over wages, or the proportion of $W$ and $R$ in relation to product $P$. If we consider (given the historical evidence) that profit is most likely to relegate wages to the status of a remainder, ${ }^{28}$ then we can understand how

\footnotetext{
27 This draws on the arguments advanced in Rodríguez Enríquez (2007) and Marco Navarro and Rodríguez Enríquez (2010).

${ }^{28}$ Profit is determined first, and the remainder (of the economic value produced) goes to wages.
} 
hard domestic labour is. Reproduction is caught between a given wage and people's needs and wants. "This is at the same time a problem of class and gender power relations, since the inverse relationship between wages and profit becomes a direct relationship between unpaid domestic labour and profit" (Picchio, 1999, p. 220).

The discrepancy between the burden of care work, its high social productivity and the scantiness of the resources allocated in the distribution to the reproduction of the working population in general reveal the extent to which the relationship between this work and the distribution of income is social and not objective. For this reason, the political demand for greater visibility for domestic and care work seeks not only to make explicit the relationship between reproductive work and social output, but also to open a debate on distribution norms, modes of production and the quality of the relationship between production and reproduction.

\section{IV}

\section{The implications of understanding and displaying the social organization and economic functionality of care}

Once the importance of incorporating the care dimension into economic analysis is accepted, numerous conceptual, methodological, political and public policy implications ensue.

Conceptually, the thrust of current developments is to delimit and clarify the substance of the ideas of care economics and social organization of care. ${ }^{29}$ Some research has concentrated on the specific study of unpaid care work, exploring its characteristics, distribution and implications. Other developments have involved a more comprehensive approach whereby the provision of care by unpaid labour in households is linked to that provided by the market (care services in the areas of education, health, personal services and, very importantly, remunerated domestic service), the State (via policies and programmes in the areas of education, health, social services and labour market regulation policies) and community and social organizations..$^{30}$

In methodological terms, a central challenge, and one deemed crucial when it comes to measuring and

\footnotetext{
${ }^{29}$ See Esquivel (2011a and b) for a state of the art on this subject.

${ }^{30}$ Here, mention should be made of: (i) the studies by the ECLAC Gender Affairs Division surveying the organization of childcare in different countries of Latin America (see Rodríguez Enríquez, 2007; Marco Navarro, 2007); (ii) the United Nations Research Institute for Social Development (UNRISD) project "Political and Social Economy of Care" which, as well as systematizing a conceptual framework for addressing the issue, is analysing a number of national cases around the world (see Razavi, 2007); (iii) the "Building Networks: Latin American women in the global care chains" project, which is studying the relationship between paid domestic service and migration dynamics (Pérez Orozco, 2009) in the creation of global care chains.
}

giving visibility to care, is to estimate the unpaid care work people do and its economic value. Two fields of study should be highlighted here: first, time-use surveys, which are the main tool for capturing situated information on the time people spend on unpaid care work; ${ }^{31}$ and second, the exercises carried out in an attempt to turn this time into some measurable economic value.

A very telling way of conveying the scale of care work in relation to the economic value societies generate is the work being done on the construction of household extensions or satellite accounts within the framework of systems of national accounts. ${ }^{32}$ Incorporating unpaid work into the "language" of national accounts means choosing a method for expressing it in monetary units. The one suggested is the input cost method, which in the case of unpaid work involves the imputation of a particular wage. Some measure of the market wage is generally taken as the benchmark. Three possible criteria come up here: (i) the global substitution method, in which the average wage for every kind of domestic activity is taken as a benchmark; (ii) the specialized substitution method, where the benchmark taken is the wage for the specific domestic activity; (iii) opportunity cost, whose benchmark is the wage that might be received by the person carrying out the domestic activity if they participated in the labour market. In this last case, the

\footnotetext{
${ }^{31}$ See Esquivel and others (2008) for a synthesis of the state of the art in this field.

${ }^{32}$ Gómez Luna (2003) presents a good synthesis of the underpinnings for these advances, as well as of concrete empirical experiences.
} 
benchmark is the wage of an employed person with similar characteristics (principally in terms of age, sex and educational level) (Benería, 2003a).

Each of these methods has its advantages and drawbacks, as well as posing a dilemma. Is it valid to equate these activities, when they are carried out under very different conditions and norms? Can productivity concepts and measures be treated as comparable in each case? Can similar parameters be used to evaluate products obtained in the market and domestic realms? The debate remains open.

Also debatable are the political consequences that flow from estimating and highlighting the scale of unpaid care work and the profiles and circumstances of those doing it. Once all this is known, should these activities be remunerated? Who should meet the economic cost of a monetary transfer rewarding unpaid care work? What form should these transfers take? Is it liberating for women for monetary recognition of this type to be implemented, or is it actually a way of entrenching their role as carers? Here again, the debate is open.

Lastly, highlighting, exposing and measuring unpaid care work and the inequitable consequences of its current organization creates a challenge for public policies. Mention may be made here of at least three implications.

The first implication relates to monetary recognition for unpaid domestic and care work. From the earliest proposal to institute a family wage to the extreme of calling for the implementation of a "housewife's wage", the debate is wide-ranging, controversial and ongoing. Recently, as a consequence of the momentum the subject has been building up in the public policy debate, some countries have incorporated components into social security reforms that seek, not necessarily to remunerate unpaid care work, but to compensate women for the income they forfeit over the life cycle by taking on these responsibilities. Examples are the application of the "child bonus" as part of the Chilean social security reform ${ }^{33}$ and the inclusion of a reckoning of contribution years for each child in the Uruguayan social security system.

The second implication is the incorporation of the gender perspective, and particularly the care dimension, into the diagnosis, design, monitoring and evaluation of all economic policies. Each and every public policy adopted operates in a field that is permeated by gender relations. Each of these also has more or less direct implications for the organization of care. Recognizing

\footnotetext{
${ }^{33}$ On this point, see Yáñez (2010).
}

these links and making them explicit is a necessary step in the effort both to enhance the impact of policies and to correct the negative biases they may have in respect of the position of women and gender equality. ${ }^{34} \mathrm{~A}$ good example in this field is gender analysis of conditional cash transfer programmes, whose controversial implications come out precisely in relation to the symbolic and practical field of care. ${ }^{35}$

The third implication concerns public policy approaches that should specifically address the issue of care and be oriented towards seeking a better distribution of these responsibilities, while at the same time opening the way to greater distributive justice. Two fields of action can once again be identified here. First, there are those initiatives that seek to facilitate reconciliation between people's work and family lives (and in fact these are called reconciliation actions or policies). These encompass State regulations in the world of paid work dealing with issues such as maternity and paternity leave, the provision of care at production units, regulation of working time and the technical organization of labour, and actions by firms themselves in these areas. ${ }^{36}$

Again, there is a field of very substantial challenges for public policies in the region, which is the need to create an extensive and accessible network of public care services provision. The vital importance of this issue can be seen when it is understood that a different way of organizing care in society is essential to progress towards equality goals. Progress has also been made in this sphere within the region, an example being the current discussion about a comprehensive national system of care in Uruguay. ${ }^{37}$

The excessive restrictions that care responsibilities impose upon poor women's access to and control of economic resources are obvious. Their situation is contributed to by: (i) greater care responsibilities (because they are usually part of large households, with more children); (ii) fewer resources to purchase care services in the market; and (iii) fewer and worse opportunities in the labour market (considering that such opportunities would give them access to resources to purchase care services in the market). Consequently, the development of an extensive network of public care services would simultaneously improve these women's

\footnotetext{
${ }^{34}$ Rodríguez Enríquez (2005) presents a synthesis of the basic links that can be identified between different dimensions of economic policy and the organization of care.

${ }^{35}$ See Rodríguez Enríquez (2011).

${ }^{36}$ ILO/UNDP (2009) presents a good systematization of the state of the debate and policies in this field in Latin America.

${ }^{37}$ See Rico (2011).
} 
(and their families') economic opportunities and ensure better conditions of care for children.

Consideration of care as a central dimension of social protection systems is a debate that is beginning to take place in the region, alongside consideration of care as a matter of rights. ${ }^{38}$ This inevitably leads on to discussion of fiscal constraints. Here, there needs to be discussion of the costs of implementing care services as compared to the (economic and social) costs of not doing so. ${ }^{39}$

${ }^{38}$ See Pautassi (2007).

${ }^{39}$ See Rodríguez Enríquez and others (2010).
Throughout this debate, it is as well to be clear about the political goal that drives it. From a feminist viewpoint, the political objective of introducing the issue of care into economic analysis is to transform its current social organization, which is considered to reproduce social and gender inequalities. Without overlooking the slow but steady progress that has been made with women's economic participation, it must be emphasized that the redistribution of care remains one of the greatest unmet challenges.

A fairer and more egalitarian society needs to be underpinned by a more equitable distribution of total work (production work and care work) and by the implementation of social and collective responsibility in the reproduction of people.

(Original: Spanish)

\section{Bibliography}

Becker, G. (1980), "El enfoque económico del comportamiento humano", ice: Revista de economía, No. 557, Madrid. (1965), "A theory of the allocation of time", Economic Journal, vol. 75, No. 299, Royal Economic Society.

Benería, L. (2003a), Gender, Development and Globalization, London, Routledge.

(2003b), "La mujer y el género en la economía: Un panorama general”, Economía y género, P. De Villota (ed.), Barcelona, Icaria.

Esquivel, V. (coord.) (2011a), La economía feminista desde América Latina: Una hoja de ruta sobre los debates actuales en la región, Santo Domingo, Gender and. Macroeconomics Group of Latin American and Caribbean (GEM-LAC), in press.

(2011b), La economía del cuidado en América Latina: Poniendo a los cuidados en el centro de la agenda, Panama City, Área Práctica de Género.

Esquivel, V. and others (2008), "Time-use surveys in the South", Feminist Economics, vol. 14, No. 3, London, Taylor and Francis.

Ferber, M. and J. Nelson (eds.) (2003), Feminist Economics Today: Beyond Economic Man, Chicago, The University of Chicago Press.

(eds.) (1993), Beyond Economic Man: Feminist Theory and Economics, Chicago, The University of Chicago Press.

Folbre, N. (2006), "Measuring care: gender, empowerment, and the care economy", Journal of Human Development and Capabilities, vol. 7, No. 2, London, Taylor and Francis. (1994), Who Pays for the Kids?, London, Routledge.

Gamba, S. (coord.) (2007), Diccionario de estudios de género y feminismos, Buenos Aires, Biblos.

Gardiner, J. (1997), Gender, Care and Economics, London, MacMillan Press.

Gómez Luna, M.E. (2003), "Macroeconomía y trabajo no remunerado", Economía y género: macroeconomía, política fiscal y liberalización: análisis de su impacto sobre las mujeres, P. De Villota (ed.), Barcelona, Icaria Editorial.

Hartmann, H. (1981), "The family as the locus of gender, class and political struggle: the example of housework", Signs, vol. 6, No. 3, Chicago, The University of Chicago Press.

Himmelweit, S. (2007), "The prospects for caring: economic theory and policy analysis", Cambridge Journal of Economics, vol. 31, No. 4, Oxford, Oxford University Press.
ILO/UNDP (International Labour Organization/United Nations Development Programme) (2009), Trabajo y familia: Hacia nuevas formas de conciliación con corresponsabilidad social, Santiago, Chile.

Mackintosh, M. (1977), "Reproduction and patriarchy", Capital and Class, vol. 1, No. 2, Sage.

Marco Navarro, F. (2007), "El cuidado de la niñez en Bolivia y Ecuador: Derecho de algunas, obligación de todas", Mujer y desarrollo series, No. 89 (LC/L.2843-P), Santiago, Chile, Economic Commission for Latin America and the Caribbean (ECLAC). United Nations publication, Sales No. S.07.II.G.168.

Marco Navarro, F. and C. Rodríguez Enríquez (2010), "Pasos hacia un marco conceptual sobre el cuidado", El cuidado en acción: Entre el derecho y el trabajo, S. Montaño Virreira and C. Calderón Magaña (coords.), Cuadernos de la CEPAL series, No. 94 (LC/G.2454-P), Santiago, Chile, Economic Commission for Latin America and the Caribbean (ECLAC). United Nations publication, Sales No. S.10.II.G.35.

Mies, M. (1986), Patriarchy and Accumulation on a World Scale, London, Zed Books.

Mincer, J. (1962), "Labor force participation of married women", Aspects of Labor Economics, H.G. Lewis (ed.), Princeton, Princeton University Press.

Nelson, J. (1996), Feminism, Objectivity and Economics, London, Routledge.

(1993), "The study of choice or the study of provisioning? Gender and the definition of economics", Beyond Economic Man: Feminist Theory and Economics, M. Ferber and J. Nelson, Chicago, The University of Chicago Press.

Nussbaum, M. (2000), Women and Human Development. The Capabilities Approach, Cambridge, Cambridge University Press.

Pautassi, L. (2007), "El cuidado como cuestión social desde un enfoque de derechos", Mujer y desarrollo series, No. 87 (LC/L.2800), Santiago, Chile, Economic Commission for Latin America and the Caribbean (ECLAC). United Nations publication, Sales No. S.07.II.G.133.

Pérez Orozco, A. (2009), "Miradas globales a la organización social de los cuidados en tiempos de crisis I: qué está ocurriendo?", Género, migración y desarrollo series, No. 5, Santo Domingo, International Research and Training Institute for the Advancement of Women (INSTRAW). 
Picchio, A. (2005), "La economía política y la investigación sobre las condiciones de vida", Por una economía sobre la vida. Aportaciones desde un enfoque feminista, G. Cairó and M. Mayordomo (comps.), Barcelona, Icaria Editorial.

(2001), "Un enfoque macroeconómico ampliado de las condiciones de vida", paper presented at the Conferencia Inaugural de las Jornadas "Tiempos, trabajos y género", Barcelona, University of Barcelona.

(1999), "Visibilidad analítica y política del trabajo de reproducción social", Mujeres y economía, C. Carrasco (ed.), Barcelona, Icaria - Antrazyt.

(1992), Social Reproduction: The Political Economy of the Labour Market, Cambridge, Cambridge University Press.

Razavi, Sh. (2007), The Political and Social Economy of Care in a Development Context: Conceptual Issues, Research Questions and Policy Options, Geneva, United Nations Research Institute for Social Development (UNRISD).

Rico, N. (coord.) (2011), "El desafío de un sistema nacional de cuidados para el Uruguay", Seminarios y conferencias series, No. 66 (LC/L.3359), Santiago, Chile, Economic Commission for Latin America and the Caribbean (ECLAC).

Rodríguez Enríquez, C. (2011), "Programas de transferencias condicionadas de ingreso e igualdad de género. ¿Por dónde anda América Latina?", Mujer y desarrollo series, No. 109 (LC/L.3416), Santiago, Chile, Economic Commission for Latin America and the Caribbean (ECLAC).
(2007), "La organización del cuidado de niños y niñas en Argentina y Uruguay", Mujer y desarrollo series, No. 90 (LC/L.2844-P), Santiago, Chile, Economic Commission for Latin America and the Caribbean (ECLAC). United Nations publication, Sales No. S.07.II.G.167.

(2005), "La economía del cuidado: un aporte conceptual para el estudio de políticas públicas", Documento de trabajo, No. 44, Buenos Aires, Interdisciplinary Centre for Public Research (CIEPP).

(2001), "Todo por dos pesos (o menos): Empleo femenino remunerado y trabajo doméstico en tiempos de precarización laboral", Documento de trabajo, No. 31, Buenos Aires, Interdisciplinary Centre for Public Research (CIEPP).

Rodríguez Enríquez, C., N. Giosa Zuazúa and D. Nieva (2010), "Las políticas de conciliación entre la vida laboral y familiar", Documento de trabajo, No. 77, Buenos Aires, Interdisciplinary Centre for Public Research.

Sen, A. (1990), "Gender and cooperative conflicts", Persistent Inequalities: Women and World Development, I. Tinker (comp.), Oxford, Oxford University Press.

(1985), Commodities and Capabilities, Amsterdam, NorthHolland.

Yáñez, S. (2010), "La dimensión de género en la reforma previsional chilena (Ley No. 20.255 de reforma de pensiones)", Mujer y desarrollo series, No. 101 (LC/L.3199-P), Santiago, Chile, Economic Commission for Latin America and the Caribbean (ECLAC). United Nations publication, Sales No. S.10.II.G.11. 